\title{
The change towards a teaching methodology based on competences: A case study in a Spanish university
}

\author{
José María González-González ${ }^{\mathrm{a}}$, José Luis Arquero-Montaño a and Trevor Hassall ${ }^{\mathrm{b}}$ \\ ${ }^{a}$ Department of Accounting and Finance, University of Seville, Seville, Spain; ${ }^{b}$ Sheffield Business \\ School, Sheffield Hallam University, Sheffield, United Kingdom
}

Dr. José María González González, Department of Accounting and Finance, University of Seville, Avda. Ramón y Cajal, 1, 41018 - Seville (Spain), Tlfno.: +34 954556050, email: jgonzalez@us.es

José María González is a Doctor Contracted in Accounting at the University of Seville (Spain) as well as a Visiting Research Fellow of Sheffield Hallam University (UK). Specific research interests include social aspects of management accounting and accounting education. He has published several papers in national and international journals about the changes caused by the implementation of European Higher Education Area and its repercussions on universities.

José Luis Arquero, after obtaining the extraordinary doctoral award of the University of Sevilla with a thesis focused in accounting education, has published several papers in this area. Most of these papers have been developed jointly with Prof. Hassall and Prof. Joyce, from Sheffield Hallam University. From those outcomes, we could highlight papers in the European Accounting Review, Accounting Forum, Accounting Education, Innovations in Education and Teaching International, Industry \& Higher Education, Education \& Training, and Journal of Vocational Education \& Training. He is the Editor of the Spanish Journal of Accounting, Finance and Management Education.

Trevor Hassall is Professor of Accounting Education at Sheffield Hallam University. He is the leader of the Accounting and Business Education Research Unit at Sheffield Hallam University and has published extensively in professional and referred journals. Specific research interests include the pedagogic use of case studies and the barriers to skills development. Other interests include the approaches to learning of accounting students and the development of vocational skills in undergraduate and professional accounting students. 


\title{
The change towards a teaching methodology based on competences: A case study in a Spanish university
}

\begin{abstract}
The European Higher Education Area has promoted the implementation of a teaching methodology based on competences. Drawing on New Institutional Sociology the present work aims to identify and improve knowledge concerning the factors which are hindering that change in the Spanish university system. This is investigated using a case study based on a Spanish university which is a pioneer in the implementation of a competence-based curriculum. The results show that factors identified and analysed are conditioning the change and causing a ceremonial adoption of the competence-based system by the teaching staff. The results of the study may be of use as a reference and orientation for educators and administrators as well as for the regulators of those countries integrated within the European Higher Education Area. The study may prove useful in the analysis of inertia factors present when designing and implementing the policies and measures necessary to achieve a comprehensive teaching methodology; one which incorporates learning and assessment of competences in a real manner.
\end{abstract}

Keywords: European Higher Education Area; Spanish higher education; teaching methodologies; competences; institutional theory.

\section{Introduction and antecedents}

The aim of the European Higher Education Area (EHEA) is to harmonize the higher education systems of the European Union countries. To enable this, the countries concerned must share common guidelines that entail, for example, the implementation of the European Credit Transfer System, a two-cycle structure of the university studies, and the quality assurance of higher education systems (Authors 2009a).

Regarding teaching methodology the guidelines of EHEA promote a competence-based system. This methodology puts the emphasis on the process of learning. Students are encouraged to take a much more active role whilst the role of teaching staff is to provide the necessary guidance in this process (López 2011). Apart from accessing specific knowledge about the subject studied the 
student's task has been expanded to the acquisition of a number of methodological competences (e.g. analysis and synthesis of information, decision-making, project management) and participatory skills (e.g. leadership, teamwork, ability to adapt to new situations). Beyond the acquisition of the relevant subject knowledge students are now expected to develop and improve their competences. As a consequence of this new approach the revised assessment system should not be based on one final summative examination. The system now includes an element of continuous assessment or evaluation such as class participation, project presentations, solving practical cases, etc.

The merits attributed to the competence-based system are several, among them can be highlighted the increased participation and autonomy of students in their learning process and the professional orientation of students who acquire and develop the knowledge, skills and practical experiences that allow them to adapt more easily to the labor markets that are characterized by a constant process of change (Martínez and Carrasco 2006).

There is an existing tradition of a competence-based teaching system mainly in AngloSaxon countries but this methodology is relatively new to the higher education systems of the countries of the south and east of Europe (Authors 2009a). In the particular case of Spain the EHEA caused a major university reform that began in 2001 with the passing of the current University Organic Law 6/2001 (Ley Orgánica de Universidades, LOU) which incorporated in the Spanish higher education the EHEA guidelines, among which was the incorporation of a competence-based system. This teaching methodology has initiated a major change since the Spanish university teachers have for decades used a teaching methodology based on the transmission of knowledge to students (content-based system), in which students had a passive role in their learning process (De Miguel 2006). Martínez and Carrasco (2006) note that although the new regulation of the Spanish university system promotes the competence-based system, its success will largely depend on the acceptance and adoption by university teachers of this new teaching methodology. Therefore, 
teachers should have the personal conviction that the change in the teaching methodology will contribute to improvements in teaching.

The literature on competence-based system is extensive. In the last decade, numerous publications analyzing different aspects related to competence-based system have been issued, such as the development of learning models (Voorhees 2001; Kennedy 2005), competence assessment systems (Baartman et al. 2007; Cano 2008), teachers training on competences (Hoogveld et al. 2005; Margalef and Álvarez 2005), benefits of the competence-based system (Martínez and Carrasco 2006; López 2011) and the promotion of teaching teams for developing this teaching methodology (Martínez and Viader 2008). However, literature concerning the factors that may hinder the implementation of the competence-based system so that this methodology becomes real is still very scarce (Mulder et al. 2009). As such it may be possible to design a teaching system based on competences, even an ideal system, but if its implementation is not carried out in a suitable manner, if the factors that may hinder the change are not taken into account and managed, it is very probable that the teaching system becomes an ideal with little impact on teaching practice and therefore it will not provide the expected benefits.

The aim of this paper is to focus on the following research question: What factors are hindering the introduction of a competence-based teaching methodology in the Spanish higher education system? The answer to this question will allow the identification of these factors, an indication of the manner in which these factors are operating. An understanding of those factors may also be useful in order to set the objectives for the adoption of measures favouring the real change of teaching methodology in the direction prescribed by EHEA. The case of the Spanish higher education could be used as a reference and orientation for the countries of the south and east of Europe whose university systems are facing a similar change in their convergence processes to EHEA. For the European countries in which the competence-based system is already established the 
paper may be informative in order to understand and assess the extent to which convergence is advancing in Southern Europe in relation to teaching methodology.

The theoretical perspective adopted in this paper for analyzing and interpreting the results of this research is the New Institutional Sociology (NIS). This theory has proven to be suitable not only for a study on the pressure generated by the institutional context on universities but also on the strategic responses of the latter to face those pressures (e.g. Etherington and Richardson 1994; Rowan 2006; Authors 2009b; Reale and Seeber 2011).

According to the NIS it could be suggested that the content-based system was institutionalized in Spain because it had acquired among teaching staff a 'taken-for-granted' status (Meyer and Rowan 1977). As a result of this status no alternatives that could challenge the system were conceived and any attempts to question it were dismissed (Tolbert and Zucker 1983). The content-based system is understood by Spanish university teachers to be the suitable and rational way to proceed in higher education (Meyer and Rowan 1977) and as a consequence it has a high number of followers (Tolbert and Zucker 1983 and 1996) and an established stability in the Spanish higher education system (DiMaggio and Powell 1983; Jepperson 1991).

However, the implementation of EHEA has created a coercive institutional pressure for a change in the teaching methodology. Those universities that conform to this institutional pressure legitimize themselves and obtain social acceptability in their contexts thus guaranteeing their own survival (Meyer and Rowan 1977; Suchman, 1995; Scott 2001).

Teachers in Spanish universities are tending to use the content-based system because it is institutionalized and therefore it is considered the natural way to teach. The use of this teaching methodology provides them with stability and certainty in the development of their teaching activity. However teachers have to conform to the institutional pressures from their environment such as the pressures from the EHEA so that the university obtains legitimacy and can assure its 
survival (Suchman 1995). One approach is to continue with the stability of the existing teaching methodology but at the same time universities can appear to achieve their adaptation to the institutional pressures by ceremonial adoption (Meyer and Rowan 1977; Kostova and Roth 2002) of the competence-based system. This type of adoption implies that the fundamentals of the old content-based system are kept active (what provides with stability and certainty) under the appearance of the new competence-based system (what provides with legitimacy in the institutional environment).

The aim of this paper is to identify and analyze the factors that are causing the inertia of the content-based system in the Spanish higher education. If those factors are not managed correctly they can cause a ceremonial or apparent adoption of the competence-based system. By identifying these factors it is possible to propose measures in order to achieve a real adoption of the competence-based system according to the requirements of the EHEA.

From the NIS perspective this type of research paper is important because research on NIS has tended to focus on the conformity of organizations to institutions (Powell 1991) as the only possible response of organizations to the pressures (coercive, normative and mimetic) of the institutional context. Oliver (1991) indicated two decades ago the need to also take into account the capacity of organizations to respond strategically to institutional pressures thus distinguishing several different responses of organizations to the conformity of the institutional pressures. This paper focuses on institutional change and considers other alternative action courses to conformity to institutional pressures. Organizations, universities and their teaching staff do not have an obligation of conform to the regulatory pressures in a 'mechanical way'; they can deliberately develop other strategies in order to compromise, avoid, defy or manipulate those institutional pressures (Oliver 1991; Etherington and Richardson 1994; Authors 2009b). 
Therefore the NIS is a suitable theoretical perspective with which to analyze and interpret the results of this study because it allows a deeper analysis of the behaviours of university teaching staff that are conditioned by those 'taken-for-granted' aspects in the higher education system. This theoretical perspective will allow consideration of the extent to which the competence-based system is truly being internalized and adopted in a real way by the teaching staff that are required to amend their teaching activity in accordance with the requirements of the EHEA.

The remainder of the paper is structured as follows: the second section is devoted to the examination of the case study as the research methodology with an emphasis on the sources of information employed: direct observation, semi-structured interviews and a review of internal and external documents as well as a series of informal conversations with faculty members. The third section presents the results of this study and, by focusing on the NIS, the forth section analyzes the factors that are hindering the real adoption of the competence-based system and therefore are causing the inertia of the old content-based system in the case investigated. The fifth section presents the conclusions and the major implications that can be derived from this study as well as indicating directions for future research.

\section{Research methodology}

To reach the objective of this study and further knowledge about the factors that are hindering the implementation of the competence-based system, a single case study has been developed concerning the teaching methodologies used in the Department of Accounting at the Anonymous University [name used to maintain the integrity of the review process].

The strategy of a single case study is recommended as the best approach to analyzing the institutional change (Dacin et al. 2002) because it allows in-depth analysis of the different factors which may influence the change. Two main reasons justify the study of a single case in this paper: 
firstly to illustrate in depth the reactions of teaching staff to the institutional pressures for changing their teaching methodology in higher education; and secondly to identify and explore the factors that can result in the ceremonial adoption of the competence-based system in Spanish higher education, generating ideas or propositions that may later become subject to rigorous empirical comparisons (Woodside 2010). The aim of this research is not the statistical generalization of results from a sample to a population, but it is to understand in depth the phenomenon investigated (Yin 1994).

The study is based on the Department of Accounting of the Anonymous University. This higher education institution, one of oldest and largest in Spain, was one of the first Spanish universities to commence adaptation to the EHEA. Thus during second half of the last decade the University started the process of curricular adaptation to the two-cycle structure (graduate and postgraduate) proposed by the EHEA and implemented the ECTS (European credit transfer system). In particular, in the middle of the previous decade, the Department of Accounting of this University was itself a pioneer in the creation of a new degree specifically in accounting and finance fully adopting the new competence-based system according to the regulations of the EHEA. So, the study of this department is highly relevant for further analysis for the purposes of this study as it provides an excellent example of the change from a content-based system to a competencebased system.

The Department of Accounting at the Anonymous University has 65 teachers and traditionally they followed a content-based system in their teaching (Jiménez and Donoso 1996). Unlike other Spanish universities where accounting is integrated into other departments such as management, financial economics, or even business organization, the Department of Accounting at the Anonymous University is specific and independent. Thus, the subject of the case study has a 
more specific boundary therefore enabling better control over the factors which have influenced the change in methodology used by the teaching staff.

The information gathered and analyzed for the purpose of this study starts in the year 2000, when the state regulation for the adaptation of the university system was approved, until 2011. As recommended for a case study by Yin (1994) the sources of information have been several. Direct observation has allowed the collection of knowledge concerning the daily activity of the department. It has also helped identify and consider the factors which have affected the process of changing teaching methodology, as intra-organizational versus external or contextual factors. Likewise a review of documentation or media gathered from different sources (institutional web pages, media, university intranet, and departmental bulletin board) has been a key in identifying and studying the influence of the factors. The documentation reviewed covers an array of internal documents of the University (internal bulletins of the Anonymous University, departmental regulations, teaching organization plans, proceedings of the departmental meetings), and external documents (state regulations, reports from the Ministry of Education and Science about the university system, reports drafted by the university unions, press news). In order to deepen the analysis, once the factors have been identified and classified, interviews were undertaken with 15 teachers of the 27 who teach on the new degree in finance and accounting. This degree was offered for the first time at the Anonymous University in the academic year 2009-2010. This new degree specifically followed the regulations of the EHEA concerning the implementation of a competencebased system. The individuals interviewed belong to different professional categories (professor, senior lecturer, assistant lecturer, etc.). The teaching staff concerned taught subjects of accounting at different stages within the degree. By means of semi-structured interviews attempts were made to gather opinions regarding the change in teaching methodology in the subject taught. 
Many informal conversations with faculty members of the department were also carried out during the process. These conversations have facilitated a contrast with the information gathered through different sources as well as to qualify some of the interpretations of information.

\section{Results of the case study}

This section firstly presents briefly the regulatory framework of Spanish higher education because it is the main pressure on Spanish universities to introduce the competence-based system. Secondly the factors that are hindering the adoption of this system are identified and the evidence concerning them is presented.

\section{Regulatory pressures for the adoption}

After the signing of the Bologna Declaration, the Spanish government approved a new law at national level to develop the requirements of EHEA and to promote the creation of competencebased system. Thus the University Organic Law 6/2001 (Ley Orgánica de Universidades, LOU) in force since 2001 states in article 87: 'The government of the country, autonomous regional governments and Universities will implement the necessary measures for the total integration of the Spanish system within the EHEA'. This fundamental law this prompted the approval of more specific regulations that configure the regulatory framework for the development of the competence-based system in the case studied:

- Royal Decree 1393/2007, Framework for University Degrees (at national level).

- Law 15/2003, Andalusian Law for Universities (at regional level).

- Decree 324/2003, New Statute of the Anonymous University (at university level). 
Additionally the Anonymous University approved in 2009 the General Rule for Teaching Activities (Anonymous University 2009) directly regulating the activities of teaching staff. All this regulation, from the LOU to the statute of the Anonymous University, highlighted that the focus should be placed on the acquisition of competences by students.

Further the Spanish Ministry of Education and Science published in 2006 the document entitled 'Proposals for the update of educational methodologies at the University' (Ministry of Education and Science 2006) with the intention of persuading university departments and their teaching staffs to adopt the competence-based system as the suitable teaching methodology in the new environment. On page 8 this document states: 'it is perceived that while teaching methodologies at the European Universities are now more focused and centred on the student's process of learning, promotion of competences and tutorial action, whilst in Spain teaching hinges mainly on lectures and their content'. Similarly the same document says on page 124:

The definition of the training profile, in which the new degrees will find its base, allows and demands higher education institutions to identify also the style of learning they would like to promote among their students (the general and specific competences which define the degree) as well as the teaching model which should subsequently follow this premise. University departments are the ones to be involved in the implementation of this process and make it fully operational through the teaching action of which they are responsible.

The Royal Decree 1393/2007 is a linchpin of the regulatory framework for the Spanish higher education. This Royal Decree establishes that one of its purposes is to make university student training meet the requirements of the labour market for a career track. Specifically it establishes that:

The curricula conducive to awarding a degree should, therefore, have as one of its central goals the acquisition of competences by the student [...] Emphasis should be placed on the learning methods towards those competences as well as on the procedures to evaluate their acquisition. 
For this reason, this Royal Decree demands that for the approval of a degree curriculum the presence of a series of new elements, such as: 'justification, goals, student's admission options, contents, planning, resources, expected results, and a system of quality assurance' (Royal Decree 1393/2007, Introduction). It also requires from universities to identify in the curriculum the specific competences that students should acquire in any proposed degree, separated from a series of basic competences (e.g. to know how to transfer knowledge into work, capacity to collect and to interpret relevant data within the field of study). This increased curricular specification had to be taken into account by the teaching staff who participated in the design of the new Degree in Finance and Accounting at the Anonymous University. In addition once the curriculum was approved teaching staff had to design a syllabus specifying goals in terms of contents to be covered as well as general and specific competences to be acquired by the student in each subject and assessment criteria.

In Spain as in other European countries (Stensaker 2011), the National Agency of Quality Evaluation and Accreditation (ANECA), which was created in 2002, is the institution responsible for the external system of evaluation of the Spanish higher education. In particular this institution is responsible for programs which address control and evaluation of different aspects within the Spanish university system. One of these programs is 'Verifica' whose main task is to evaluate and verify curricula designed by the universities for the different degrees adapted to the EHEA and importantly it guarantees the acquisition of competences by the student. Among other things the program states that (ANECA 2008, 14):

The goals of the degree must be pertinent, and the competences to be acquired by the students must be in agreement with the requirements to award a degree as established by EHEA qualifications [...] Competences to be acquired by the student should be coherent and susceptible of assessment. 


\section{Inertia factors}

The inertia factors that are causing the resistance to the change promoted by the regulatory pressures above mentioned and therefore are favouring the continuity of the old teaching methodology based on contents, are the following ones: little training in competences for teaching staff, lack of agreement regarding expectations about the new system, functional and structural disadvantages, weak internal coordination, absence of supervision and ambiguity of criteria of the new system. The following section will present the evidence collected about each of these factors.

\section{Little training in competences for teaching staff}

From the middle of the past decade the Anonymous University has allocated material and human resources to courses for teaching staff in order to train them in the competence-based system and in the related information technologies. Therefore almost $70 \%$ of the voluntary courses offered at the beginning of 2010 were related to the competence-based system and its support technologies. Among these courses, publicised in their web page are the following:

- 'An approach to teaching design and planning through Internet using WebCT in its application within EHEA'

- 'WebCT communication tools and their application in EHEA'

- 'Website design for pedagogical purposes: its applications in EHEA'

- 'New utilities for virtual classrooms with WebCT'

- 'Interactive teaching with Educlick portal services'

The Anonymous University has been also allocating $€ 125,000$ per year since 2006 to support and finance innovation projects of individual teachers and teams which address issues 
related to improvement of teaching in the EHEA. The official announcement to apply for this financing states (Anonymous University 2008, Agreement 6.1. CG 28-10-08):

Those projects related to a methodology change with an orientation towards learning and assessment of competences complementary to those specific competences of the courses will be considered a priority. Likewise, projects which promote the use of active teaching methodologies and the design and application of new assessment systems will also be prioritized.

In spite of the resources devoted by the Anonymous University to training of the teaching staff in the competence-based system, one of the teachers interviewed stated: "not all teachers understand the competence-based system in the same way, we don't share an objective definition, and in the end we find shelter in the transmission of knowledge which is the system we know best'. Identifying the reasons why there is no widely held to view about the system; the main cause is that the teaching staff have little training in the competence-based system. Every teacher interviewed admitted that he or she had a general idea but only $20 \%$ of the people interviewed considered that they had enough knowledge in order to put the system into practice. As one of the faculty members stated: 'even though we'll have a general idea about the competence-based system, training is still scarce. I have attended several courses about the competence-based system, but I admit not to know enough about how to implement it and put into practice'. The majority of the people interviewed indicated that the training received regarding the system was mostly of an academic nature and not oriented to facilitate setting into practice a teaching approach based on competences. Also $66 \%$ of the people interviewed (10 teachers) stated that the courses offered by Anonymous University only dealt with specific aspects of the system. One of the people interviewed commented:

I believe that this training about competences should be mandatory for teaching staff. Moreover the training offered should be continuous and better structured, that is to say, there should be a training program based on an established and suitable path that the teacher can follow in order 
to acquire the necessary training which would enable him or her to put the system into practice later on.

\section{Lack of agreement regarding expectations about the competence-based system}

In this instance when considering the expectations of teaching staff about the competencebased system it is noticeable that the people interviewed consider the system adequate since it contributes to bridging the gap between students and the idea of a professional career. For the accounting profession in particular Albrecht and Sack (2000) pointed out this gap and also indicated the coincidence between accounting professionals and lecturers who both value highly the acquisition of competences by students in order to practice their future profession.

However, criticism among faculty members set obstacles for the establishment of the competence-based system as the suitable teaching methodology. Criticism made suggested that: most people interviewed indicated that the competence-based system focuses too much on the target-nature of education, making the system all too rigid; the system is easy to present but difficult to put into practice; it requires a greater involvement in the process of learning which the student fails to attain.

Most of the people interviewed agreed indicating that the content-based system worked under the assumption that the main objective should be placed in covering a broad range of contents in depth in order to prepare students to be able to apply this knowledge later when they joined the labour market. Subsequently, the implementation of EHEA opened a period of reflection concerning the necessity to train the student in complex job related tasks and therefore to offer training oriented towards professional practice. This reflection promoted a trend in favour of reducing content to focus on the necessary competences for a professional career. However, as the most of interviewees expressed, it is causing a reduction in contents not compensated for by an increase in the acquisition of competences in the courses offered. 


\section{Functional and structural disadvantages}

By taking a deeper look into the shortcomings of a competence-based system the present study has been able to define two types: functional and structural. The first shortcomings identified referred to the problems related to the actual putting into practice the teaching methodology; whereas the second group refers to specific characteristics of the university under study which condition the functionality of a competence-based system. Among the functional disadvantages mentioned in interviews is identified the difficulty to assess the acquisition of competences due among other things to the arbitrariness it entails and to the scarce training teachers have to carry it out. In this respect many of interviewees stated that the system of evaluation in their subjects was designed to assess mainly the knowledge acquired by the student irrespective of the requirement to prove acquisition of competences. In fact the assessment method with the highest percentage assigned, approximately $70 \%$ (and in some cases $100 \%$ of the final grade if the student chooses as an option offered to avoid the requirements of other types of projects rejecting the principle of continuous assessment) is still a written test to assess the knowledge acquired by the student at the end of the year.

Other important functional disadvantages mentioned by the interviewees were: a low-level of commitment of the student with his or her process of learning and their subsequent access to the professional track, this in turn produces a negative outcome in the form of a tendency to lower the level of effort and even to plagiarize (as it is the case in some of the team projects required); work overload for teaching staff and students, continuing with the same number of students even though evaluating competences requires a greater effort; in the case of the students, higher number of projects and papers to complete. Concerning this last aspect, one of the people interviewed made the following statement widely shared by the rest: 
In the majority of the courses, team projects have become a normal task which produces too much variety and dispersion. Students go from one project to another without enough time to acquire, much less absorb, the contents. In the end, the final goal seems to be to get projects and requirements out of the way as soon as possible.

With respect to the structural disadvantages mentioned by the people interviewed the following are to be noted:

Among structural disadvantages that affect the design, the accounting professional profile is not clearly defined in Spain. This situation makes rather difficult to identify the competences to be acquired by accounting students as prescribed by the guidelines for the degree in finance and accounting. In general terms, the new syllabi reduced the coverage and depth of contents to be dealt with in most subjects.

Other disadvantages refer to the implementation of the changes. The number of students per group is still high (an average of 75 students per group). This situation is a key constraint to introduce active pedagogy, to pursue the development of competences or even to assess complex tasks. Most of the classrooms are rigidly designed for large number groups thus restricting the possibility to work with smaller groups. The academic level of the students pursuing the degree tends to be lower in comparison with students choosing other degrees (such as economics or business administration). Finally a number of teachers resist change and they have tried to approach teaching the same way that they have in the past, because it requires a lesser effort. As one of the teachers interviewed stated: 'the competence-based system entails a greater workload for the teacher without any compensation whatsoever'.

\section{Weak internal coordination}

Another important factor was the lack of a planned and coordinated approach to the delivery of the competence-based system in the subjects taught by teaching staff. Of the people interviewed $100 \%$ 
stated that in their opinion there was no coordination whatsoever preparing them for the teaching and assessment of competences in the different subjects they taught. As one of them observed:

We have not dealt with how to tackle the question of competences in full. We say what we expect, we name the competences, but we do not know how we're going to carry out the actual teaching and evaluation on the basis of competences acquired.

The focus among the different subjects and courses remains just on the contents to be taught and the planning of those contents throughout the year; with respect to competences there is no action. Another interviewed teacher stated: 'there is criteria and consensus about contents, but not about competences; this usually remains the domain of every teacher'. Since the new regulations require that the syllabi of every course should establish the competences to be acquired by students the usual practice has been to fulfil this requirement as essentially a paper exercise. Another teacher indicated in this respect: 'My subject is not structured on the basis of competences. Competences do appear in the syllabus of the subject though it is only for the sake of fulfilling administrative demands'. Another one stated: 'We have not reflected deeply upon the question of competences. They have been incorporated into the syllabi of the courses though one thing is what you find on paper and another is what you do afterwards'.

\section{Absence of supervision}

The majority of the people interviewed said that there was no control whatsoever regarding the effective development and implementation of the competence-based system in the process of learning. The only control mentioned by the people interviewed was the one related to the contents to be taught in accordance with the scheduled planning previously established in the syllabus. Such control was also of an informal in nature. Currently there is no internal supervision in the 
Department or Faculty for ensuring that the teachers are following the competence-based system in their education activity.

Likewise, there is no effective external supervision on the application of the competencebased system by teaching staff. In this respect, another program of ANECA is 'Docentia', which has as its main goal to provide Spanish universities with the necessary directives to establish a system to evaluate the performance of the teaching staff. This program specifically states the main aspects to be included in such an evaluation and in particular "whether the educational activity of the teaching staff, taking into consideration the resources at his/her disposal, propitiates among students the acquisition of competences as described in the curriculum' (ANECA 2006, 13). However all the interviewees pointed out that ANECA and universities can check if the competences to be acquired by students appear in the syllabi of the subjects but they cannot check if teaching staff are delivering the competence-based system in order that students can acquire those competences. As an interviewee noted, 'ANECA and universities check if the competences appear in the syllabus and then they suppose teachers adopt the competence-based system. They make this assumption because they cannot check the actual adoption of that system by teaching staff'.

\section{Ambiguity of criteria}

The last inertia factor identified in this study is the ambiguity of concepts and criteria in respect of the competence-based system as perceived by the teaching staff. Of the interviewees $60 \%$ agreed that the competence-based system is marred with ambiguities. In particular the interviewees perceived ambiguity in: the concept of competences, capacities, and skills, as these aspects tend to be confusing and to occupy the same space; a notion of competence assessment, because it is not clear what to evaluate and how. As one of the teachers remarked: 'We don't really know what is expected, we only have a general idea. The moment we try to go deeper into the competence-based 
system, we only find doubts'. Ambiguity has become an uncertainty factor regarding the competence-based system among the teaching staff and this has made its final implementation difficult.

\section{Discussion of results}

The acquisition of competences by students is essential in order to practice as an accounting professional. This suggestion is included in several professional pronouncements of relevant organizations in the area of finance and accounting (e.g. AECC 1990; AICPA 1992; UNCTAD 1998; IFAC 2010) and it is supported by the research conducted in several countries (e.g. Clarke 1990, in Ireland; Bhamornsiri and Guinn 1991, in USA; Hassall et al. 1999, in England; Arquero et al. 2009, in Spain). The implementation of the EHEA has proposed a change in this direction because it promotes the competence-based system as teaching methodology. However several factors are hindering its introduction in the Spanish case investigated. The NIS perspective may improve our understanding concerning the influence of these factors.

According to the NIS the institutional environment is consisting of three institutional pillars (Scott 2001): (1) regulatory that involves the establishment of rules, the supervision of its fulfilment and the imposition of punishments in case of non-observance, in an attempt to influence future behaviour; (2) normative that refers expectations and norms shared by individuals about 'the right thing to do', by designating appropriate ways to pursue the goals or objectives; and (3) cognitive that refers to the shared views which constitute the nature of social reality and influence the way in which events are interpreted. The adoption and consolidation of a new practice in organizations, such as the competence-based system in universities is facilitated when the mentioned pillars support that new practice. However in the case studied, we found problems with the introduction and consolidation of the competence-based system regarding the three institutional pillars. 
Analysing the regulatory pillar, the regulatory framework of Spanish higher education is exerting pressure on universities to the adoption of the competence-based system. This pressure is not being effective. One of the main reasons is that research activity is more valuable for teaching staff than their teaching activity in terms of professional promotion and salary (Authors 2009c) and this belief is institutionalized in the Spanish context. As it is noted by Martínez and Carrasco (2006, p. 18), 'In practice, the teaching activity is underestimated and directly despised in the academic evaluation of teaching staff'. Moreover, the new regulatory framework has increased the gap in the evaluation of the research and teaching activities of university lecturers (Delgado and Fernández 2012). In particular the research activity is formally evaluated against very competitive standards whereas the appropriateness of the teaching activity is assumed and underestimated. Thus as the new teaching methodology implies an increased workload that is not valued and there is not a real supervision of the teaching activity that may entail the imposition of sanctions the regulatory pressure on teaching staff to use the competence-based system is very limited.

In this context the persuasion of university teachers is important to achieve a real adoption of the new teaching methodology. Several persuasive pressures have taken place in the case studied such as the publication of "Proposals for the update of educational methodologies at the University" (Spanish Ministry of Education and Science 2006), the training courses on competences offered by the Anonymous University to its teaching staff, and the program 'Docentia' of ANECA. In this sense, as it is noted by Martínez and Carrasco (2006, p. 10), 'The changes must be made by persuasion $[\ldots]$ The regulatory framework is necessary but still true that teachers and students have the key to the new university to be achieved'.

Similarly as it is shown from the results, some necessary changes for implementing the competence-based system in the Spanish university context characterized traditionally by mass registrations (Mora and Vidal 2005; Langa and David 2006) have not been sufficiently taken into 
account. In the case studied although the coercive institutional pressure derived from the regulatory pillar is promoting the change (DiMaggio and Powell, 1983), the structural disadvantages identified, such as the absence of an accounting profile clearly defined (as happens in other European countries such as the UK), the high number of students per group and the classrooms designed for large number groups, are conditioning and questioning the technical suitability (Powell 1991; Scott and Meyer 1994; Zeitz et al. 1999) of the competence-based system, making its adoption and implementation difficult. In this respect as it is noted by Huber (2008, p. 59), the competence-based system 'implies the implementation of educational and physical environments that allow an active teaching and learning'.

Regarding the normative pillar, as the competence-based system is not institutionalized, there is not a wide consensus among the teaching staff about this teaching methodology and there is resistance from teachers to this new methodology (Tolbert and Zucker 1996; Greenwood et al. 2002). The results of the case study show that the expectations about the 'right teaching methodology to apply" are not shared by the teaching staff and there are criticism among them about the new system. Therefore the normative pillar is not supporting the introduction of the new teaching methodology.

As well as the criticism concerning the competence-based system, the weak internal coordination and the absence of supervision are causing the principles and norms of this teaching methodology (e.g. focus on the learning process, active role of students, learning objectives based in competences and continuous assessment) not to be uniformly adopted and implemented by the teaching staff. These factors are hindering the replication of behaviours which are fundamental for the consolidation of a new practice (Barley and Tolbert 1997). According to Zeitz et al. (1999) coordination and supervision are very important during the introduction of a competence-based 
system by ensuring its correct application will achieve the desired results and promoting a greater visibility of the value of this teaching methodology for students.

Importantly the main objective of teaching staff is still to teach the theoretical knowledge of subjects irrespective of the acquisition of competences by students. In fact this acquisition of competences is not currently being evaluated by most of teachers. As the results show the competences are introduced in the syllabi of subjects in order to comply with the administrative requirements but not to comply with the education requirements of the competence-based system. The focus of subjects remains on the contents to be taught and the assessment system focuses mainly on the knowledge acquired by students. All these facts are very indicative of a ceremonial adoption (Meyer and Rowan 1977; Kostova and Roth 2002) of the new teaching methodology in the case studied or as it is identified by Mulder et al. (2009, p. 764), 'the bureaucratic use of competence instruments in academic education'. As it is highlighted by De Miguel (2006, p. 17), 'once the competences have been established, the planning of a subject requires to specify the suitable teaching methods so that such competences are acquired by students, as well as the assessment criteria and procedures to be used in order to check if the competences have been really acquired by students'.

Conversely support of the cognitive pillar is mainly limited by the ambiguity of criteria and little training in competences for teaching staff. Both factors hinder the understanding of the competence-based system in practice and cause a superficial adoption whose main objective is apparent visibility and legitimacy. Practices introduced in this way are unlikely to be embraced by teachers and therefore have a higher risk of not being used in a realistic way or even rejected (Tolbert and Zucker 1996; Kostova and Roth 2002).

The results of the case study show that the teaching staff still have many doubts concerning the competence-based system due to the ambiguity of the concepts and criteria used which 
discourage them from fully engaging with this teaching methodology. This has also been highlighted by Carreras (2006) and Weigel et al. (2007). Specifically Carreras (2006) analyzed the terminology regarding the concept of 'competence' used in several media (documents of EHEA, norms of the Spanish Ministry of Education and Science, norms of ANECA, guidelines of universities, and publications of education experts). He concluded that 'efforts need to be made in order to use the expression competence is used in a univocal way [...] most university teachers do not have the enough necessary psicopedagogical knowledge to avoid the confusion introduced' (Carreras 2006, p. 85). Our results confirm the ambiguity surrounding the concept of competence in practice because the main confusion for the teaching staff of the Accounting Department is defining the concept and identifying a suitable system to assess the extent students have acquired the required competences in their learning process.

The training and development underpinning the introduction of a new methodology is fundamental for its entrenchment among staff because it allows the transmission of beliefs, values and technical information about the practice and facilitates its internalization. (Zeitz et al. 1999). In this study the teaching staff were trained in competences but this training was unstructured and noncompulsory. Margalef and Álvarez (2005) suggest that training of teaching staff in competences should be voluntary. However several interviewees thought that this training should be compulsory because teachers must have at least a basic training about the competence-based system and how to implement it. Also as teachers can avoid using the new teaching methodology and its adoption supposes an effort that is not rewarded in terms of promotion or salary (Authors 2009c) the compulsory nature of the training in competences may be advisable.

The ambiguity mentioned above coupled with the possible lack of training have affected the internalization of the competence-based system by teaching staff. This can explain several functional disadvantages that have been identified in this case study including the difficulty of 
assessing the acquisition of competences by students and the work overload for students who have problems in covering the technical content whilst carrying out the planned activities for competence development.

Regulatory institutional pressures have promoted the competence-based system and they have caused the 'erosion' (Oliver, 1992; Scott 2001; Dacin and Dacin 2008) of the content-based system which was institutionalized in Spanish higher education. This erosion of the content-based system, in particular can be seen in this case in the following facts: all syllabi must specify the general and specific competences to be acquired by the student; the content of the syllabus subjects has been reduced and reoriented so that the learning is more focused on the development of professional practice; and apart from the traditional final written exam to evaluate content acquired by students other forms of testing have been introduced for assessment (mainly team projects). However even though the content-based system has been eroded the adoption and implementation of the competence-based system have been mainly impaired by the inertia factors analysed. It is possible to identify the permanence of institutional remnants (Dacin and Dacin 2008) which have prevented the real implementation of a competence-based system, such as the pervasiveness of the expository method oriented to the transmission of knowledge to be learned by the student: the student's process of learning is still highly dependent on the teaching by the teacher; the assessment method is still focused on the acquisition of knowledge by students; and finally the permanence of some structural factors characteristic of the content-based system such as the great size and design of classrooms and the high number of students per group.

\section{Final considerations}

The aim of this study was to identify and analyze the factors which are hindering the adoption and implementation of a teaching methodology focused on the acquisition of competences by students 
in Spanish higher education. A single case study was conducted around the teaching carried out by the members of the Department of Accounting at the Anonymous University in Spain on the new degree in finance and accounting.

The identification of these factors shows that the change to a competence-based system has been promoted by the regulatory pillar of the institutional context, although the regulatory pressures to change are not being effective. Also the normative and cognitive pillars of the institutional context of Spanish universities are conditioning the level of adoption of the new teaching methodology. In the case studied currently the syllabi of subjects specify the competences that are to be acquired by the accounting students but the teaching methodology is not yet focused on competences. As the competence-based system has been implemented but the teaching staff have not internalized the principles and norms of this teaching methodology; the adoption has not been real or effective but rather ceremonial.

The NIS has helped us to show that the change proposed by the Declaration of Bologna has entailed an 'erosion' of the content-based system but not its total rejection. In addition even though the competence-based system has replaced the content-based system, the discontinuity of the latter has not fully taken place. Instead, despite being partially eroded their foundations still survive under the new competence-based system.

The analysis of the factors identified demonstrates that there is a need for measures leading to the real adoption and full implementation of the competence-based system. These measures should contribute to secure an ample consensus among the teaching staff regarding the valuable role of the methodology as well as the internalizing and consolidation of the different concepts, norms, and values associated. Conversely if those factors are not identified and managed, measures are not taken and such a consensus is not reached, the implementation of the new methodology would end up being merely ceremonial: a formal implementation of the competence-based system on the part 
of the teaching staff in order to meet the requirements of external institutional pressure, without actually sharing the belief that the methodology represents a real value added in terms of their teaching. Some of the measures that could be taken to achieve the effective implementation of a competence-based system are:

- The promotion of a program of continuous and better structured training in the competencebased system for the teaching staff. Training oriented to classroom practice and designed to reduce ambiguity about concepts and criteria within the system.

- The creation of incentives for those teachers who get actually involved in the full implementation of the competence-based system by giving them the recognition for professional promotions or remuneration bonuses.

- Regarding functional disadvantages. The clear definition of competences in order to allow the full assessment, coordination of the different tasks and projects assigned to students in the different courses to avoid an overload of work for every student and enforcement of disciplinary measures for those students who plagiarize.

- Regarding structural disadvantages. Reduction of the number of students per group to better monitor competence learning, adaptation of classrooms for groups with fewer students and increment of entry level requirements for students in order to guarantee the commitment of the student.

- The establishment of a new internal coordination between teachers of every subject regarding the specific details of the competence-based system as well as a supervised follow-up by the teaching staff to better control and improve the system when necessary.

- The implementation of competence-based assessment in all courses including feedback to evaluate the success of the whole system and to make recommendations about pertinent 
adjustments in the future. As it is clearly pointed out by Gulikers et al. (2008) and Mulder et al. (2009, p. 766), 'a competence-based curriculum requires competence-based assessment because a misalignment of these two is detrimental for learning'.

The results of the present study may be relevant and applicable to other disciplines and other participant countries in EHEA. The reason for this is that many of the inertia factors identified and analyzed in this work have a direct impact on university teaching regardless of discipline. Also the problems and factors identified may be common to other countries where the full implementation of the competence-based system as part of the declaration of Bologna has not yet been fully consolidated. When designing the necessary and effective policies and measures to implement the competence-based system and its assessment this study may be a useful reference to educators, educational administrations, and regulators.

Further research is needed to analyze the degree in which the competence-based system being implemented in Spanish universities is having any impact on the learning style of the students and whether such an impact is superficial or deep (Biggs 1987; Authors 2010). Also, it would be interesting to analyze how the process of 'translation' (Sahlin and Wedlin 2008) of the competencebased system into the universities in Spain and other European countries of the EHEA has taken place. This would allow us to understand how the differences in institutional contexts in the differing countries may have generated differences in the configuration and understanding of the competence-based system adopted and implemented in each individual country. 


\section{References}

AECC (Accounting Education Change Commission) 1990. Objectives of education for accountants (Position Statement No. 1). New York: AECC.

AICPA (American Institute of Certified Public Accountants) 1992. Academic preparation to become a certified public accountant. New York: AICPA.

Albrecht, W.S., and Sack, R. 2000. Accounting education: Charting the course through a perilous future. Accounting Education Series 16. Sarasota: American Accounting Association.

ANECA. 2008. Informe sobre el estado de la evaluación externa de la calidad en las universidades españolas. Madrid: ANECA.

ANECA. 2006. Protocolo de evaluación para la verificación de títulos universitarios oficiales. Madrid: ANECA.

Anonymous University. 2008. Agreement 6.1. CG 28-10-08, First Scheme for Educational Development (Primer Plan Propio de Docencia). Anonymous University. http://vdocencia.us.es/vicerrectorado-de-docencia/plan-propio-dedocencia/documentos/iplanpd_cg_28_10_08

Anonymous University. 2009. Agreement CU 5-2-09, General Rule for Teaching Activities (Reglamento General de Actividades Docentes). BOUS no. 2, 10 February 2009.

Arquero, J.L., Donoso, J.A., Jiménez, S.M., and González, J.M. 2009. Exploratory analysis of the demanded professional profile on business administration degree: Implications for the accounting area. Spanish Accounting Review 12, no. 2: 181-213.

Arquero, J.L., J.M. González, T. Hassall, J. Joyce, E. Germanou, and S. Asonitou. 2010. The approaches to learning of European accounting students. EuroMed Journal of Business 5, no. 3: 345-62.

Baartman, L.K., Bastiaens, T.J., Kirschner, P.A., and Vleuten, C.P.M. 2007. Evaluating assessment quality in competence-based education: A qualitative comparison of two frameworks. Educational Research Review 2, no. 2: 114-129.

Barley, S.R., and Tolbert, P.S. 1997. Institutionalization and structuration: Studying the links between action and institution. Organization Studies 18, no. 1: 93-117.

Bhamornsiri, D., and Guinn, R.E. 1991. The road to partnership in the 'Big Six' firms: implications for accounting education. Issues in Accounting Education 6, no. 1: 9-24.

Biggs, J.B. 1987. Student approaches to learning and studying. Australia: Australian Council for Educational Research.

Cano, M.E. 2008. La evaluación por competencias en la educación superior. Revista de Currículum y Formación del Profesorado 12, no. 3: 1-16.

Carreras, J. 2006. Competencia y planes de estudio. In Propuestas para el cambio docente en la universidad, coords. M. Martínez and S. Carrasco, 75-89. Barcelona: Octaedro-ICE.

Clarke, P.J. 1990. The present and future importance of curriculum topics relevant to accounting practice: A study of Irish perceptions. Dublin: University College. 
Dacin, M.T., Goodstein, J., and Scott, W.R. 2002. Institutional theory and institutional change: Introduction to the special research forum. Academy of Management Journal 45, no. 1: 4557.

Dacin, M.T., and Dacin, P.A. 2008. Traditions as institutionalized practice: Implications for deinstitutionalization. In The Sage Handbook of Organizational Institutionalism, ed. R. Greenwood, C. Oliver, K. Sahlin and R. Suddaby, 327-351. London: Sage Publications.

Decree 324/2003, New Statute of the Anonymous University (Estatuto de la Universidad Anónima). BOUS 1, 27 September 2008.

De Miguel, M. (coord.) 2006. Metodologías de enseñanza y aprendizaje para el desarrollo de competencias. Madrid: Alianza Editorial.

Delgado, F.J., and Fernández, R. 2012. Sobre la evaluación del profesorado universitario: Especial referencia a Ciencias Económicas y Jurídicas. Revista Española de Documentación Científica 35, no. 2: 361-375.

DiMaggio, P.T., and Powell, W.W. 1983. The iron cage revisited: Institutional isomorphism and collective rationality. American Sociological Review 48, no. 2: 147-160.

Etherington, L.D., and Richardson, A.J. 1994. Institutional pressures on university accounting education in Canada. Contemporary Accounting Research, special education research issue: 141-162.

González, J.M., and T. Hassall. 2009. The changes to accounting education and accounting educators as a result of changes in the Spanish university system: A case study using an institutional theory approach. The International Journal of Management Education 7, no. 3: $13-25$.

González, J.M., J.L. Arquero, and T. Hassall. 2009a. Bologna and beyond: A comparative study focused on UK and Spanish accounting education. Higher Education in Europe 34, no. 1: $113-25$.

González, J.M., J.L. Arquero, and T. Hassall. 2009b. Pressures and resistance to the introduction of skills in business administration and accounting education in Spain: A new institutional theory analysis. Journal of Vocational Education and Training 16, no. 1: 85-102.

Greenwood, R., Suddaby, R., and Hinings, C.R. 2002. Theorizing change: The role of professional associations in the transformation of institutionalized fields. Academy of Management Journal 45, no. 1, 58-80.

Gulikers, J.T.M., Kester, L., Kirschner, P.A., and Bastiaens, T.J. 2008. The effect of practical experience on perceptions of assessment authenticity, study approach, and learning outcomes. Learning and Instruction 18, no. 2: 172-186.

Hassall, T., Joyce, J., Arquero, J.L., and Donoso, J.A. 1999. Vocational skills and capabilities for management accountants: a CIMA employer's perspective. Management Accounting (UK), December: 52-56.

Hoogveld, A.W.M., Paas, F., and Jochems, W.M.G. 2005. Training higher education teachers for instructional design of competency-based education: Product-oriented versus processoriented worked examples. Teaching and Teacher Education: An International Journal of Research and Studies 21, no. 3: 287-297. 
Huber, G.L. 2008. Aprendizaje activo y metodologías educativas. Revista de Educación, extra: 5981.

IFAC (International Federation of Accountants). Education Committee. 2010. Handbook of International Education Pronouncements. 2010 Edition. New York: IFAC.

Jepperson, R.L. 1991. Institutions, institutional effects, and institutionalism. In The new institutionalism in organizational analysis, ed. W.W. Powell and P.J. DiMaggio, 143-163. Chicago IL: The University of Chicago Press.

Jiménez, S.M., and Donoso, J.A. 1996. Estado de opinión sobre la docencia en contabilidad: Una encuesta a los profesores de Universidad. Revista Española de Financiación y Contabilidad 25, no. 89: 961-999.

Kennedy, A. 2005. Models of continuing professional development: A framework for analysis. Journal of In-Service Education 31, no. 2: 235-250.

Kostova, T., and Roth, K. 2002. Adoption o fan organizational practice by subsidiaries of multinational corporations: Institutional and relational effects. Academy of Management Journal 45, no. 1: 215-233.

Langa, D., and David, M. 2006. A massive university or a university for the masses? Continuity and change in higher education in Spain and England. Journal of Education Policy 21, no. 3: 343-365.

Law 6/2001, University Organic Law (Ley Orgánica de Universidades). BOE no. 89, 21 December 2001.

Law 15/2003, Andalusian Law for Universities (Ley Andaluza de Universidades). BOJA no. 251, 31 December 2003.

López, J.I. 2011. Un giro copernicano en la enseñanza universitaria: formación por competencias. Revista de Educación 356: 279-301.

Margalef, L., and Álvarez, J.M. 2005. La formación del profesorado universitario para la innovación en el marco de la integración del Espacio Europeo de Educación Superior. Revista de Educación, no. 337: 51-70.

Martínez, M., and Carrasco, S. (coords.) 2006. Propuestas para el cambio docente en la universidad. Barcelona: Octaedro-ICE.

Martínez, M, and Viader, M. 2008. Reflexiones sobre aprendizaje y docencia en el actual contexto universitario. La promoción de equipos docentes. Revista de Educación, extra, 213-234.

Meyer, J.W., and Rowan, B. 1977. Institutionalized organizations: Formal structure as myth and ceremony. Amercian Journal of Sociology 83, no. 2: 340-363.

Ministry of Education and Science. 2006. Proposals for the update of educational methodologies at the University (Propuestas para la renovación de las metodologías educativas en la Universidad). Madrid: Ministerio de Educación y Ciencia.

Mora, J.G., and Vidal, J. 2005. Two decades of change in Spanish universities: Learning the hard way. In Reform and change in higher education: Analysing policy implementation, eds. A. Gornitzka, M. Kogan and A. Amaral, 135-152. The Netherlands: Springer. 
Mulder, M., Gulikers, J., Biemans, H., and Wesslink, R. 2009. The new competence concept in higher education: error or enrichment?. Journal of European Industrial Training 33, no. 8/9: 755-770.

Oliver, C. 1991. Strategic response to institutional processes. The Academy of Management Review 16, no. 1: 145-179.

Oliver, C. 1992. The antecedents of deinstitutionalization. Organization Studies 13, no. 4: 563-588.

Powell, W.W. 1991. Expanding the scope of institutional analysis. In The new institutionalism in organizational analysis, ed. W.W. Powell and P.J. DiMaggio, 183-203. Chicago IL: The University of Chicago Press.

Reale, E., and Seeber, M. 2011. Organisation response to institutional pressures in Higher Education: The important role of the disciplines. Higher Education 61, no. 1: 1-22.

Rowan, B. 2006. The new institutionalism and the study of educational organizations: Changing ideas for changing times. In The new institutionalism in education, ed. H.D. Meyer and B. Rowan, 15-32. New York: State University of New York Press.

Royal Decree 1393/2007, Framework for University Degrees (Ordenación de las Enseñanzas Universitarias Oficiales). BOE no. 260, 30 October 2007.

Sahlin, K., and Wedlin, L. 2008. Circulating ideas: Imitation, translation and editing. In The Sage Handbook of Organizational Institutionalism, ed. R. Greenwood, C. Oliver, K. Sahlin and R. Suddaby, 218-242. London: Sage Publications.

Scott, R.W. 2001. Institutions and organizations. Foundations for organizational science. $2^{\text {nd }}$ edition. Thousand Oaks, CA: Sage Publications.

Scott, R.W., and Meyer, J.W. 1994. Institutional environments and organizations. Thousand Oaks, CA: Sage Publications.

Stensaker, B. 2011. Accreditation of higher education in Europe - moving towards the US model? Journal of Education Policy 26, no. 6: 757-769.

Suchman, M.C. 1995. Managing legitimacy: Strategic and institutional approaches. The Academy of Management Review 20, no. 3: 571-610.

Tolbert, P.S., and Zucker, L.G. 1996. Institutionalization of Institutional Theory. In Handbook of Organizational Studies, eds. S. Clegg, C. Hardy, and W. Nord, 175-190. London: Sage Publications.

Tolbert, P.S., and Zucker, L.G. 1983. Institutional sources of change in the formal structure of organizations: The diffusion of civil service reforms 1880-1935. Administrative Science Quarterly 50: 35-67.

UNCTAD (United Nations Conference on Trade And Development) 1998. Guideline for a global accounting curriculum and other qualifications requirements. Geneva: UNCTAD Secretariat.

Voorhees, R.A. 2001. Competency-based learning models: A necessary future. New Directions for Institutional Research, no. 110: 5-13. 
Weigel, T., Mulder, M., and Collins, K. 2007. The concept of competence in the development of vocational education and training in selected EU member states. Journal of Vocational Education and Training 59, no. 1, 51-64.

Woodside, A.G. 2010. Case study research: theory, methods, practice. Bingley: Emerald.

Yin, R.K. 1994. Case study research: Design and methods (2nd edition). Thousand Oaks, CA: Sage Publications.

Zeitz, G., Mittal, V., and McAulay, B. 1999. Distinguishing adoption and entrenchment of management practices: A framework for analysis. Organization Studies, 20, no. 5: 741-776. 